\title{
Corporate governance, bank mergers and executive compensation
}

Article

Accepted Version

Liu, Y., Padgett, C. and Varotto, S. (2017) Corporate governance, bank mergers and executive compensation. International Journal of Finance \& Economics, 22 (1). pp. 1229. ISSN 1099-1158 doi: https://doi.org/10.1002/ijfe.1565 Available at https://centaur.reading.ac.uk/66907/

It is advisable to refer to the publisher's version if you intend to cite from the work. See Guidance on citing.

To link to this article DOI: http://dx.doi.org/10.1002/ijfe.1565

Publisher: Wiley-Blackwell

All outputs in CentAUR are protected by Intellectual Property Rights law, including copyright law. Copyright and IPR is retained by the creators or other copyright holders. Terms and conditions for use of this material are defined in the End User Agreement.

\section{www.reading.ac.uk/centaur}

\section{CentAUR}

Central Archive at the University of Reading

Reading's research outputs online 


\title{
CORPORATE GOVERNANCE, BANK MERgers AND EXeCUTIVE COMPENSATION
}

\author{
Yan Liu \\ Carol Padgett \\ Simone Varotto \\ ICMA Centre \\ ICMA Centre \\ ICMA Centre \\ Henley Business School Henley Business School Henley Business School
}

\begin{abstract}
Using a sample of US bank mergers from 1995 to 2012, we observe that the pre-post merger changes in CEO bonus are significantly negatively related to the strength of corporate governance within the bidding bank. This suggests that bonus compensation is not consistent with the "optimal contracting hypothesis". Salary changes, on the other hand, are not affected by corporate governance which is in line with "optimal contracting". We also find that good governance is associated with more accretive deals for the bidder. Overall, our results are consistent with the notion that, unlike salary and long-term compensation, bonus compensation is not aligned with value creation and is more vulnerable to CEO manipulation in banks with poor corporate governance.
\end{abstract}

JEL classification: G21, G28, G34

Keywords: Corporate Governance, Bank Mergers, Executive Compensation, Bonus 


\section{Introduction}

The level of CEO compensation and its relationship with performance have been controversial topics following the recent financial crisis. Views diverge on the efficacy of compensation contracts in maximizing firm value and containing risk taking. Compensation in the financial industry, especially the large bonus packages paid to CEOs of underperforming banks, has attracted mounting criticism. As a result, from the beginning of 2014 the European Union has placed a cap on bankers' bonuses. ${ }^{1}$ CEO compensation that engenders excessive risk taking and weak corporate governance more generally - has been cited as an important cause of the financial crisis by the OECD (Kirkpatric 2009). Against this backdrop it is surprising that little academic research has looked at the link between CEO compensation and corporate governance in the banking industry. In this paper, we provide evidence of the effects of corporate governance on CEO compensation in the context of bank mergers. Mergers provide a suitable laboratory to study CEO compensation as they are often accompanied by significant changes in firm valuation, performance and risk. The academic literature has found evidence of significantly higher levels of CEO compensation after M\&A deals. ${ }^{2}$ In this study, we focus on the "optimal contracting hypothesis" in which CEO interests are assumed to be aligned with those of shareholders (see, for example, Core et al., 1999). Optimal contracting leads to CEO compensation that is positively and significantly related to firm value, and unrelated to the strength of corporate governance within the firm. This is because optimal contracting resolves the agency problem between CEO and shareholders and hence makes the heightened monitoring effected by good governance irrelevant. For our analysis, we use Thomson One Banker to source 214 domestic bank mergers in the US announced between 1995 and 2012. We look at the US because it is one of the most active markets for corporate control. It has also been the epicentre of the Great Recession of 2007-2009 which has led to an international agreement on compensation guidelines, together with national legislation, to constrain short termism and risk taking in banks. ${ }^{3}$

\footnotetext{
1 The cap is $200 \%$ of salary. See Jill Treanor, European banks to get new guidelines on bonus cap and 'allowances', 13 June 2014, The Guardian.

2 See, for example, Bliss and Rosen (2001) and Anderson et al. (2004).

${ }^{3}$ In 2009, the Financial Stability Board (FSB) introduced principles of sound compensation practices that are "aligned with long-term value creation and prudent risk-taking". The principles further state that "[f]or senior executives as well as other employees whose actions have a material impact on the risk
} 
Our work contributes to the literature in the following ways. First, as far as we are aware, this is the first paper that examines how corporate governance affects CEO compensation around bank mergers. While previous studies have looked at industry diversified samples (e.g. Grinstein and Hribar, 2004 and Harford and Li, 2007), we concentrate on banks because of the distortions that compensation policies can produce on bank behaviour and the resulting impact on financial stability. ${ }^{4}$ Second, we show that the optimal contracting hypothesis can be accepted or rejected depending on the components of CEO compensation it is tested on, namely, salary, bonus or long term compensation. We find that while salary satisfies optimal contracting, the bonus component is significantly reduced by the strength of corporate governance which provides evidence against the null. This suggests that bonus compensation is not necessarily related to firm value creation. On the other hand, changes in long term compensation around mergers have a distinct behaviour that differs from that of salary and bonus. Indeed, long term rewards do not appear to be explained in any meaningful way by governance or performance variables. Third, we introduce a new index (CGI) to measure the strength of corporate governance. The index is purpose-built with hand collected data from company filings and considers 11 key drivers of good governance including board composition, CEO power, antitakeover measures, ownership concentration and legal environment. ${ }^{5}$ Fourth, we provide evidence that the risk dimension is a crucial determinant of CEO compensation. Both changes in salary and

exposure of the firm: (1) a substantial proportion of compensation should be variable ... (2) a substantial portion of variable compensation, such as 40 to 60 percent, should be payable under deferral arrangements over a period of years; (3) these proportions should increase significantly along with the level of seniority and/or responsibility. Further, "Subdued or negative financial performance of the firm should generally lead to a considerable contraction of the firm's total variable compensation, taking into account both current compensation and reductions in payouts of amounts previously earned, including through malus or clawback arrangements." The implementation of these principles has been undertaken by the Basel Committee on Banking Supervision (see BCBS (2010)), the International Association of Insurance Supervisors (IAIS) and the International Organization of Securities Commissions (IOSCO). Similar principles have been embedded in the Dodd-Frank Act that was signed into law in the United States in 2010.

${ }^{4}$ Federal Reserve Chairman Ben S. Bernanke stated that "Compensation practices at some banking organizations have led to misaligned incentives and excessive risk-taking, contributing to bank losses and financial instability". (press release October 22, 2009, Board of Governors of the Federal Reserve System)

${ }^{5}$ Our approach is consistent with Jensen and Meckling (1976) and Shleifer and Vishny (1997), who see corporate governance as a way to mitigate agency problems which arise from the separation of ownership and control. We are aware of an even broader perspective of corporate governance which involves a greater spectrum of stakeholders, such as depositors, employees, suppliers, society as a whole, etc. However, for the purpose of this study, we focus on corporate governance as a means to solve the agency problems between shareholders and managers. 
bonus are negatively related to the risk taken by the bidding bank's CEO, measured as the bidder's stock price volatility around a merger. Moreover, when looking at banks that sought government support during the recent subprime crisis, we find that boards penalise higher risk taking by reducing CEO salary. However, though bonus changes were lower in banks that required government funding, the banks' risk taking does not appear to have influenced bonus compensation.

In line with previous literature (Masulis et al. 2007; Hagendorff et al. 2007, 2010), we also find that corporate governance is an important value driver for bidder abnormal returns, after controlling for other firm and deal related characteristics. For example, our governance index alone can explain up to $6.8 \%$ of the variations in bidders' abnormal return around merger announcements. This suggests that good governance may lead to higher shareholder value.

This paper proceeds as follows. In Section 2 we review relevant literature. We describe our data and the composition of the corporate governance index in Sections 3 and 4. In Section 5 we describe our regression model. Sections 6 and 7 summarise our main findings and robustness tests. Section 8 concludes the paper.

\section{Literature review}

Our research is related to a strand of the literature that examines the effects of corporate governance on CEO compensation. Hallock (1997) find that interlocking directorships significantly increase CEO compensation. Borokhovich et al (1997) look at the effect of antitakeover charter amendments (ATAs) on the level of CEO compensation, and find that ATA adopting firms pay their CEOs significantly higher levels of compensation after controlling for other board and CEO characteristics and economic factors. Core et al. (1999) find that companies with weaker monitoring from the board of directors and a lack of shareholder control generally pay higher CEO compensation. Cyert et al (2002) also find that internal governance mechanisms such as ownership by the board and the largest blockholder provide an effective control on CEO compensation, especially on equity-based compensation. Bebchuk and Fried (2005) measure CEO power within the firm and conclude that the more powerful the CEO, the 
higher, and less sensitive to performance, the compensation level. Focusing on payperformance sensitivity, Bertrand and Mullainathan (2001) provide evidence supporting the "skimming model", which contradicts the "optimal contracting hypothesis". The authors find that CEOs are paid for luck, though this effect is reduced with strong corporate governance. Focusing on the banking industry, Sierra et al. (2006) observe that a strong board is associated with lower levels of compensation and slower increase in compensation. Also studying the banking industry but only focusing on privately held commercial banks, Cooper (2009) finds that board independence reduces both executive and director compensation. Moreover, directors receive higher pay in banks with better CAMELS (Capital, Asset, Management, Earnings, Liquidity, and Sensitivity) ratings.

Our study is also related to research studying CEO compensation and mergers. Grinstein and Hribar (2004) find that the M\&A related bonus paid to the CEO of the bidding firm is not affected by deal performance or bidding firm's return on assets. However, measures of effort and CEO power are both significantly associated with a higher merger related bonus. Harford and Li (2007) find evidence that M\&As insulate pay-performance sensitivity. While CEOs gain after value-increasing deals, they do not lose after value-destroying deals. However, pay-performance sensitivity when performance is poor is improved with strong governance. Yim (2013) finds significant increases in all major components of compensation following a merger. Also, while bonus increases subside 2 years after the acquisition, the increase in salary and equity based pay is more resilient. Therefore, the author predicts that younger CEOs are more likely to undertake acquisitions to reap long term compensation gains, and finds evidence that an increase in age of 20 years is associated with a $32 \%$ reduction in the probability that the CEO will undertake an acquisition. In the banking industry, Bliss and Rosen (2001) look at the largest bank holding companies in the US and find that CEO compensation increases significantly even for merger deals with negative stock price reactions. The authors conclude that the private benefit of increased compensation may motivate CEOs to engage in bank mergers. Anderson et al (2004) also find significant increases in cash and total compensation paid to acquiring firm CEOs. However, they ascribe the increase in compensation to combined value changes of the bidder and target banks. They argue that combined value changes of bidder and target 
indicate expected synergies from the merger, which need managerial efforts to be realized.

The third strand of relevant literature includes studies that link bank CEO compensation to risk taking. Chen et al. (2006) find that equity-based compensation has the effect of increasing bank risk. Hagendorff and Vallascas (2011) focus on merging banks, and show that higher pay-risk sensitivity induces greater risk-taking incentives in bank M\&A deals ${ }^{6}$. However, to the best of our knowledge, there is little evidence on whether CEOs are rewarded or punished for risk-increasing M\&A deals.

\section{Data}

We obtain our initial sample of 478 domestic US bank mergers from the Thomson One Banker dataset, after imposing the following criteria:

1. The deal is completed.

2. The deal is announced between 1 Jan 1995 and 31 Dec $2012^{7}$.

3. There is a change in control. Following Faccio et al (2006) and Golubov et al (2012), we require that the bidder owns less than $10 \%$ of the shares of the target bank before the merger announcement, and raises its shareholding to above $50 \%$ after deal completion.

4. We select deals in the banking industry, with both bidder and target banks classified as "Commercial banks, or Bank Holding Companies" in Thomson One Banker ${ }^{8}$.

5. We choose only completed deals with acquirer market capitalization of at least $\$ 100$ million, measured 4 weeks before merger announcement, and at least $10 \%$

\footnotetext{
${ }^{6}$ Datta et al. (2001) also find that high pay-performance sensitivity is associated with increased stock return volatility post-merger in general industries.

${ }^{7}$ The year of 1995 is selected as the beginning of the sample period because 1994 is the year from which Proxy Statements containing CEO compensation data and the corporate governance data are widely available on SEC Edgar website.

${ }^{8}$ This industry classification is based on the SIC code of the primary line of business, collected by Thomson One Banker. The SIC codes for the sample bidder and target banks fall into the following four categories: 6021 (National Commercial Banks), 6022 (State Commercial Banks), 6029 (Commercial Banks, Not Elsewhere Classified), and 6712 (Bank Holding Companies).
} 
relative deal size, measured as the ratio between target's and acquirer's market capitalization ${ }^{9}$.

6. The bidding bank is public while the target bank can be public or private.

7. As in Alexandridis et al (2010), we exclude spin-offs, recapitalizations, selftenders, exchange offers, and repurchases. From the sample, we further exclude liquidations, leveraged buyouts, reverse takeovers, privatizations, bankruptcy acquisitions and going private deals, as in Golubov et al (2012).

8. We include only non-overlapping deals. That is, we exclude cases where one acquirer makes multiple bids within two consecutive years. This is to avoid a compounding effect on CEO compensation (Harford and Li, 2007).

9. We then require that the bidder's financial statements, stock prices and SEC Edgar filings are available for the years around the merger.

The above criteria reduce the sample size from 487 to 214 . For the remaining transactions, we extract deal-related information from Thomson One Banker. We obtain financials from Datastream and stock data from CRSP. We have hand collected information on gender and education of the acquiring firm's CEO from annual reports or if the data were not available there, from Bankscope. Summary statistics are reported in Table 1. We can see that the target is on average $30.7 \%$ the size of the bidder and is mostly a public company (69.6\% of the cases). Only $22.7 \%$ of the deals are paid with cash. Almost half of bidders and targets are headquartered in the Mid-Atlantic (New Jersey, New York, and Pennsylvania) and South-Atlantic (Delaware, Florida, Georgia, Maryland, North Carolina, South Carolina, Virginia, Washington D.C., and West Virginia) regions. About two third of acquirers and targets are national commercial banks, as opposed to state banks or holding companies. 96.7\% of the acquiring CEOs are male, while only a quarter holds an MBA.

To examine the changes of CEO compensation around bank mergers we hand collect CEO salary, bonus, and long term compensation from Proxy Statements (DEF 14A file) which are available on the SEC Edgar website. The data prior to the merger are collected at the fiscal year-end before merger announcement, and the compensation

\footnotetext{
${ }^{9}$ We focus on larger deals relative to the size of the acquirer as they are more likely to have an impact on the compensation of the acquiring CEO.
} 
level after the merger is collected at the fiscal year-end of merger completion ${ }^{10}$. Long term compensation is the sum of the dollar value of restricted stock, stock option grants (valued as reported by the company in the Proxy Statement), long term incentive plans (LTIPs), and other long-term compensation. In Table 2 we look at CEO compensation data for the subsamples with continuing CEOs (Panel A), new internally promoted CEOs (Panel B), and new externally promoted CEOs (Panel C). It can be seen that compensation significantly increases post-merger only for the subsample with continuing CEOs. As shown in Panel A, the mean (median) increase in salary is $\$ 31,000$ ( $\$ 30,000)$, and both figures are statistically different from zero at the $1 \%$ significance level. The average bonus increase is positive though not significant, but the median bonus increase of $\$ 12,000$ is positive and significant. ${ }^{11}$ The mean (median) increase in long-term compensation is $\$ 310,000(\$ 60,000)$, and both numbers are statistically significant. Although the average ratio of long-term compensation to annual cash compensation is 0.995 before merger, the proportional increase in longterm compensation is significantly larger post-merger, resulting in an average pay mix of 1.216 post merger with an increase of $22 \%$. This is consistent with Anderson et al. (2004) who find long term compensation increases at a faster pace than annual cash compensation. Contrary to the findings in Panel A, Panel B shows that new internally promoted CEOs receive significantly reduced levels of salary, while changes in bonus and long term compensation are not statistically significant. Panel C looks at compensation changes for new CEOs who are hired externally. Here the sample is too small (7 observations) to draw any firm conclusions. Following Harford and Li (2007), for the purpose of examining the effects of firm-, deal-, and corporate governance factors on CEO compensation changes around M\&A deals, we focus on the subsample of continuing CEOs.

\footnotetext{
${ }^{10}$ For example, if a bank merger is announced on 16 May 2005 and completed on 2 Feb 2006. Assuming the fiscal year end is 31 December (which is the case for the $99 \%$ of our sample banks), then the CEO compensation data is collected for the fiscal year of 2004 and fiscal year 2006.

${ }^{11}$ Here we should clarify that the positive and significant median in the Table has been computed on the cross-section of bonus changes, not simply as the difference between pre- and post-merger medians. The latter approach does not take into account the distribution of the changes and hence it would not be an appropriate measure. For the average, on the other hand, this calculation issue does not apply as the average of the changes is the same as the difference between pre and post-merger averages.
} 


\section{Corporate Governance Index}

Previous researchers have combined corporate governance characteristics into indices that were found to be strongly positively correlated with firm valuation and stock returns (Gompers et al. 2003; Bebchuk et al. 2009; Brown and Caylor 2006) ${ }^{12}$. In this study we follow a similar approach. We use a selection of governance indicators drawing from existing theory, empirical evidence and data availability for the firms in our sample. The indicators cover 6 areas of corporate governance namely anti-takeover provisions, the intensity of board monitoring, strength of monitoring by external shareholders, CEO power on the board, the extent to which CEO interest is aligned with shareholder interest, and the state of incorporation (i.e. whether the bidding bank is incorporated in the state of Delaware). We hand collect the corporate governance data from two major sources: SEC Edgar website (for proxy statements DEF-14A, 10-Q and 10-K filings) and Thomson One Banker (for the Poison Pill data). Our index variables are 11 dummies that take the value 1 to indicate good corporate governance practice and 0 otherwise. Then, the values of all the dummies for each bidding bank are added up to form the bank's Corporate Governance Index (CGI), which measures the overall strengths of corporate governance. We discuss the motivation behind each index component in detail below.

\section{Anti-takeover Provisions}

Firstly, we look at two types of anti-takeover measures, i.e. the presence of a "staggered board" and the inclusion of "poison pills" in the bank's bylaws. Both variables appear in the 24-provision G-index of Gompers et al. (2003), the 6-provision E-index of Bebchuk et al. (2009), and the 3-provision external ATI-index of Cremers and Nair (2005). All these authors find that the two variables are associated with significantly lower firm value and stock returns. The "Staggered Board" and "Poison Pill" dummies are given a value of 1 if, before the merger announcement, the firm does not have a

\footnotetext{
12 Bebchuk et al. (2009) select 6 most important factors from the G-index of Gompers et al. (2003) and build an "Entrenchment Index". The authors find that this parsimonious index has the same ability to explain the variations of firm value and abnormal returns as the G-Index. The other 18 factors are not important value or return drivers. Brown and Caylor (2006) utilize the ISS database with 51 factors covering a broad range of external and internal corporate governance characteristics, and find that better corporate governance, indicated by either the 51 full index (Gov-Score) or the parsimonious index (Gov$7)$, is significantly positively associated with firm value.
} 
staggered board and a poison pill respectively, and 0 otherwise. We then add these two dummies together to form a sub-index, "Sub_ATP", to measure the ability of the bank to repel a takeover. A higher score indicates lower anti-takeover ability, i.e. better corporate governance indirectly obtained through the disciplining effect of potential takeovers.

\section{Board Monitoring}

Larger boards are less effective in communication, are more prone to free-riding problems, have less incentive to obtain information, and are more subject to CEO influence (Jensen 1993). Yermack (1996) finds that board size is significantly negatively related to firm valuation. On the other hand, the number of independent board members is found to have a positive impact on firm value, because outside directors have objectives that are better aligned with those of shareholders (Brickley and James 1987; Rosenstein and Wyatt 1990). For the board size dummy, we give a score of 1 to a firm with board size smaller than our sample median, and 0 otherwise. For the board independence dummy, we assign a score of 1 to a firm with higher than median percentage of non-executive directors ${ }^{13}$. We then add the two variables together to obtain the "Sub_Board" sub-index that measures the strengths of board monitoring.

\section{Shareholder Monitoring}

Shleifer and Vishny (1986) stress the importance of monitoring by large shareholders. There is also evidence that the existence of large external shareholders is associated with greater control of CEO compensation (Cyert et al. 2002; Bertrand and Mullainathan 2003; Hartzell and Starks 2003). Here we focus on the monitoring effect of large outside blockholders, who are not employees of the bank and hold more than $5 \%$ of common equity of the bidding bank (Core et al. 1999). We expect that the existence of a large external blockholder provides efficient monitoring and reduces CEO entrenchment ${ }^{14}$. We assign a score of 1 if the bidding bank has existing external blockholders, and 0 otherwise. This score is called "Sub_Blockholder".

\footnotetext{
${ }^{13}$ We do not have data on "independence" of directors, therefore we use the ratio of "non-executive director" to proxy for board independence.

${ }^{14}$ We do not consider the existence of internal blockholders who are employees of the bidding bank. The reason is that after examining our sample, the majority of internal blockholders are CEOs (there are
} 


\section{CEO Power}

To measure the extent to which the CEO can influence board decisions we look at CEO duality, that is whether the CEO is also the Chairman of the board, and if he or she sits on the nomination or compensation committees (Bebchuk et al. 2002; Bebchuk and Fried 2003; Grinstein and Hribar 2004). Having an independent compensation committee is among the measures recommended by the Dodd-Frank Act (Carpenter et al. 2010). Core et al. (1999) and Cyert et al. (2002) find that CEOs who are also board chairmen receive compensation $20 \%$ to $40 \%$ higher than others. A CEO sitting on the nomination committee or compensation committee signals the lack of independence of the committees and the significant power the CEO has on selecting board nominees ${ }^{15}$ and their compensation levels. Grinstein and Hribar (2004) find that CEO duality and presence in the Nomination Committee lead to higher M\&A related bonus for the CEO. We assign a score of 1 to the following three distinct CEO power dummies when the CEO is not the Chairman of the board, does not sit on the nomination committee, and does not sit on the compensation committee. If a CEO has too much power on a board, he is less likely to protect shareholder interest and more likely to extract a rent to his own benefit. We also combine these three indicators and add their scores to obtain a sub-index called "SUb_CEO_Power".

\section{CEO-Shareholder Alignment}

The two variables used to indicate alignment of managerial and shareholder interests are CEO shareholding and CEO tenure. Managerial equity ownership is one of several important solutions to the agency problem resulting from the separation of ownership and control. Indeed, it is found to be positively related to firm performance and valuation (Agrawal and Knoeber 1996; Amihud et al. 1990). Consistent with the argument that CEO shareholding aligns CEO interest with shareholder interests, Core et al (1999) and Cyert et al. (2002) find that the level of CEO compensation is significantly negatively related to the percentage of CEO shareholding. On the other

only 2 cases where the internal blockholder is not the CEO). Thus, we exclude internal blockholders to avoid double-counting the effect of CEO ownership.

15 Sometimes, the bidding bank does not have an existing nomination committee, and the nomination and selection of board members are performed by the board of directors as a whole. In this cases, we treat them as if CEO sits on the committee because effectively the CEO will have greater power on board member selection. 
hand, there are different interpretations of the relationship between CEO tenure and the strength of corporate governance. High CEO tenure can indicate high CEO power and entrenchment ${ }^{16}$. In contrast, CEO tenure can also be an indicator of the quality of CEO, insofar as CEOs who have done a good job at protecting shareholder value are more likely to remain in office longer. Also long standing CEOs are more likely to have accumulated the firm specific skills and knowledge that enable them to perform better on the job. We support this latter interpretation and consider tenure as a positive indicator of CEO-shareholder alignment. We measure CEO tenure as the number of years the CEO has been serving on the board of directors ${ }^{17}$. The two dummies that capture CEO shareholding and tenure are given a value of 1 to indicate high level of alignment with shareholder interest, i.e. when the CEO has above median percentage of share ownership and above median tenure relative to other CEOs in the sample. The sum of these two variables, "Sub_CEO_Shareholder", indicates the extent to which the CEO attends to shareholder interest.

\section{Delaware}

The last aspect of corporate governance we include in our corporate governance index relates to the State of incorporation. We look at whether the bidding bank is incorporated in Delaware whose corporate legislation is more "pro management" than other states (Cary 1974). Danielson and Karpoff (1998) find that Delaware firms have more anti-takeover provisions compared to non-Delaware firms, and the difference is statistically significant. We assign a score of 1 to bidding banks which are not incorporated in Delaware, to indicate stronger corporate governance, and 0 otherwise. This variable is named "Sub_Delaware".

In Table 3 we present summary statistics for our governance indicators (Panel A) and the distribution of the Corporate Governance Index (Panel B and Figure 1). Interestingly, Figure 1 shows that the CGI gradually increases during the 18 years of

\footnotetext{
${ }^{16}$ With longer board tenure, the CEO may have more influence over the board members who are selected by the CEO (Baker and Gompers 2003) and there is also evidence that longer CEO tenure is associated with less equity-based pay and higher levels of annual cash compensation (Fahlenbrach 2009).

${ }^{17}$ We couldn't obtain data on the years the CEO has held the title of CEO as not all firms report this data in the proxy statement. Our measurement of CEO tenure using the years of the CEO being on the board of directors is consistent with Fahlenbrach (2009).
} 
our sample. If we compare the CGI of the second half of the sample period (2004 to 2012) to the first half (1995 to 2003), we see a statistically significant difference between the means (5.91 to 7.02) and medians (6 increases to 7). The break point of our two sample periods (year-end 2003) coincides with the time surrounding the passage of the Sarbanes-Oxley Act (2002) and the changes in subsequent listing requirements on the major US exchanges. Our findings suggest that such measures may have been effective in increasing the strength of corporate governance, at least in the banking industry.

\section{Model}

In our study we test the "optimal contracting hypothesis" by employing CEO compensation changes around bank mergers. CEO compensation satisfies optimal contracting when it is designed to maximize firm value. The level of compensation is the result of supply and demand in the executive recruitment market, and the effort level that the CEO exerts in managing the firm. In the "hidden action" model by Holmstrom (1979), performance measures (such as accounting profitability or stock returns) and firm value measures (such as $\mathrm{M} / \mathrm{B}$ ratio) are used to proxy for the effort exerted by the CEO. If the CEO compensation is optimal, then there is no role for corporate governance as the CEO will not have the remuneration incentives to extract rent even when corporate governance is poor. Moreover, bank CEO compensation should not encourage excessive risk taking which, as the subprime crisis has amply demonstrated, could have a detrimental impact on the survival of the bank and the stability of the financial system.

The model we use to test the above is:

$$
\Delta \text { Compensation }_{i}=\alpha_{i}+\beta_{1} \text { FIRM }+\beta_{2} D E A L+\beta_{3} C G+\beta_{4}[Y E A R \text { DUMMIES }]+\varepsilon_{i}
$$

where the dependent variable COmpensation $_{i}$ is the changes in natural log of different forms of CEO compensation from the fiscal year before the merger announcement to the fiscal year of the deal completion, similar to Anderson et al. (2004) and Avery et al. (1998). The individual dependent variables are calculated using the following formulas: 
$\Delta$ Salary $_{i}=\mathrm{LN}($ Post-merger salary $)-\mathrm{LN}($ Pre-merger salary $)$

$\Delta$ Bonus $_{i}=\mathrm{LN}($ Post-merger bonus + Pre-merger salary $)-\mathrm{LN}($ Pre-merger bonus + Premerger salary)

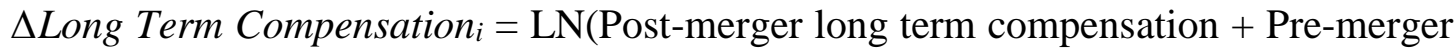
salary) - LN(Pre-merger long term compensation + Pre-merger salary)

FIRM is a vector of firm-specific financial characteristics which are related to compensation, DEAL is a vector of deal-related factors, and CG represents our corporate governance measures.

\section{Results}

We start our analysis of CEO compensation by looking at its salary component. As we can see from Table 4 Panel A, variations in CEO salary and changes in the M/B ratio are positively and statistically significantly related. This suggests that the post-merger salary of the bidding bank's CEO may factor in his effort to increase growth opportunity through the merger. The finding is in line with the optimal contracting hypothesis and with previous literature where firm growth potential is proxied by the $\mathrm{M} / \mathrm{B}$ ratio (Core et al. 1999; Harford and Li 2007) or Tobin's Q (Hartzell and Starks 2003; Ozkan 2012). Further, changes in firm risk, measured as the bidder's daily stock return volatility over the fiscal years around the merger, significantly reduce CEO salary post-merger. Interestingly, deal-related characteristics are not found to affect salary changes. Specifically, a popular measure of deal quality, the cumulative adjusted return (CAR3), does not have a statistically significant coefficient. This suggests that CEOs are not penalised when they complete bad deals. The result contrasts with Anderson et al (2004) who find that changes in compensation are positively associated with bidder's stock return around a merger. Turning to the focus of this study, our corporate governance index (CGI) is negatively related to salary changes, but its coefficient is not statistically significant. When we replace our CGI index with its constituent sub-indices in Panel B, we obtain qualitatively similar results. Again, this is confirmation of optimal contracting as far as CEO salary is concerned. Lastly, we find that the bidder size before the merger is strongly negatively related to CEO salary changes. Although CEO 
compensation is commonly found to increase with firm size, this finding is not surprising as we look at compensation changes instead of levels. Since CEOs of larger banks will normally have larger pre-merger salaries than smaller banks, their increase following a merger may be relatively lower than for smaller banks.

With respect to bunus compensation, we find that the changes in $\mathrm{M} / \mathrm{B}$ ratio are negatively and significantly related to changes in CEO cash bonus. This suggests that companies experiencing higher growth through M\&As tend to have relatively lower cash bonus increases. A plausible explanation is that high growth bidders and their CEOs prefer the variable components of compensation to be based more on stock options rather than cash. This is because stock options are better able to capture the upside potential of a fast growing business while at the same time bringing into line CEO's and shareholders' interests. Stock options are typically included in the long term component of the CEO compensation package. Indeed, the $\mathrm{M} / \mathrm{B}$ ratio is positively related to long term compensation, though not statistically significant. Consistent with Grinstein and Hribar (2004), we find that bidder announcement returns do not significantly improve bonus-related payments post-merger. Contrary to Grinstein and Hribar (2004), however, measures of effort such as deal relative size, geographical diversification, and time to complete the deal do not significantly affect the changes in bonus payment.

The negative and significant coefficient of CGI for bonus compensation suggests that as the strength of corporate governance increases, changes in bonus around bank mergers decline. The implication is that bonus does not satisfy the optimal contracting hypothesis as the terms of the contract are not solely driven by CEO performance. The size of the CGI coefficient indicates that, following an increase of 1 point in the CGI (i.e. by changing 1 of the 11 corporate governance measures from "bad" to "good"), CEO bonus declines by $5.4 \%$ relative to the pre-merger salary level. Panel B of Table 4 shows that the significance of the CGI coefficient is mainly due to the CEO power sub-index. This result is consistent with Grinstein and Hribar (2004) who also focus on the power of the CEO in increasing merger-related bonus payment. Finally, we find evidence that CEOs receive lower bonus post-merger if bank risk is increased due to the merger. This result is in line with our findings for salary. 
Turning to long-term compensation, the main finding is that it is not explained by the common factors that influence salary and bonus. None of the explanatory variables is significant with the exception of RELATIVESIZE. As the size of the target relative to the bidder increases so does the downside potential of the transaction. So increasing long term compensation with the relative size of the target may act as a form of insurance to help secure a longer term commitment on the part of the CEO to make the merger work. CGI (Panel A) and its sub-indices (Panel B) in general do not appear to affect long term compensation changes. R-squared across specifications is very low. Such results provide limited evidence of "optimal contracting".

One may wonder if the stronger alignment between shareholders' and CEO's interests brought about by stronger corporate governance actually translates into higher shareholder returns around mergers. We examine the relationship between CGI and bidder announcement return measured over several event windows. We firstly run the regression with CGI (and a constant term) only. Results are shown in Panel A in Table 5. Across event windows between 1 to 21 days, CGI has consistently positive and statistically significant coefficients. We then include control variables (Panel B). Following Masulis et al. (2007), we add bidder size, leverage, M/B ratio of assets, premerger stock return as firm financial characteristics, and relative deal size, public target dummy variable, method of payment, and geographic diversification as deal-related characteristics plus the usual controls. The positive coefficient of CGI on bidder abnormal return persists across specifications. It is also significant for most CARs. Other control variables are not statistically significant.

\section{Robustness}

We undertake a number of robustness tests. Firstly, we consider whether executive compensation restrictions imposed on banks that requested government support during the recent subprime crisis would affect the influence of the corporate governance index on CEO compensation. TARP (Troubled Asset Relief Program) is a program whose aim was to assist troubled institutions during the financial crisis from 2008 onwards. All recipients of TARP are subject to executive compensation restrictions for as long 
as they have not repaid the funding received from the Treasury ${ }^{18}$. We obtain the status of bidding bank as a TARP recipient from Propublica ${ }^{19}$, which provides information on the dates and value of the initiation of the relief program and the following repayments made by the recipient. If the bidding bank receives TARP assistance and undertakes a merger during the assistance period, we assign a TARP RECIPIENT dummy a value of 1 , and 0 otherwise. In addition, we interact the $\triangle$ RISK variable with TARP RECIPIENT to examine whether being a TARP recipient and making a merger deal during the time of TARP assistance would lead the bidding bank to have a different attitude towards merger-related risk. TARP was intended to stabilize the financial sector through capital injections and asset purchases but at the same time encouraged additional loans which might increase risk taking. As found by Black and Hazelwood (2013), loan origination risk increased in large TARP banks but fell in small TARP banks. Results in Table 6 show that our main findings do not change. Interestingly, while TARP banks generally pay lower salaries and bonuses post-merger compared to non-TARP banks, TARP banks punish risk-increasing CEOs by reducing salary rather than bonus. In terms of using lowering compensation to control additional risk-taking through bank mergers, TARP has a better control of salary payment compared to bonus.

In unreported results, we also changed the form of dependent variable to the dollar value of compensation changes (instead of using the changes in natural log of compensation levels) and obtain qualitatively the same coefficients for CGI. Furthermore, we control for CEO's age in the regressions to account for the possibility that younger CEOs are more likely to undertake acquisitions in order to benefit from the increased compensation after acquisitions (Yim 2013). The inclusion of CEO age does not qualitatively change our results for CGI.

\section{Conclusion}

Using a sample of US bank mergers from 1995 to 2012, we find that CEO salary changes around bank mergers are not influenced by the strength of its corporate

\footnotetext{
${ }^{18}$ For details of TARP on compensation, please refer to http://www.treasury.gov/initiatives/financialstability/TARP-Programs/executive-comp /Pages/overview.aspx

${ }^{19}$ http://projects.propublica.org/bailout/list
} 
governance. This suggests that CEO salary is typically set to align CEO's interests with those of shareholders, a condition that satisfies the "optimal contracting hypothesis". However, cash bonus changes are negatively related to firm performance and are clearly influenced by the quality of corporate governance. The implication is that the cash bonus is not set to maximise shareholder value. We also find that the strength of corporate governance is significantly positively associated with bidder announcement returns. So, poorly governed banks appear to undertake acquisitions that are detrimental to shareholders, but reward their CEOs with higher post-merger bonuses. Our results support the recent move by bank regulators to favour compensation packages for senior executives that are mostly variable and deferred over a number of years. Unlike cash bonuses, such deferral arrangements allow for reductions in payouts of amounts previously earned through clawbacks and malus, which are designed to bring into line CEO objectives with those of the firm (FSB 2009).

The fact that regulators are becoming so much more involved in compensation arrangements suggests that internal mechanisms need improvement. The growing literature on the work of compensation consultants and their relationships with directors is interesting and valuable in this respect, but tends to focus on total remuneration (Rennebooog and Zhao, 2011). Our results show that different forces are at work in the setting of salaries, bonuses and long-term incentives. Future research should consider the individual components of compensation with the objective of ensuring that there are no perverse incentives within the package. 


\section{References}

Agrawal, A., and C. R. Knoeber. 1996. Firm performance and mechanisms to control agency problems between managers and shareholders. Journal of Financial and Quantitative Analysis 31 (03):377-397.

Alexandridis, G., D. Petmezas, and N. Travlos. 2010. Gains from mergers and acquisitions around the world: new evidence. Financial Management 39 (4):1671-1695.

Amihud, Y., B. Lev, and N. G. Travlos. 1990. Corporate control and the choice of investment financing: The case of corporate acquisitions. Journal of Finance 45 (2):603-616.

Anderson, C. W., D. A. Becher, and T. L. Campbell Ii. 2004. Bank mergers, the market for bank CEOs, and managerial incentives. Journal of Financial Intermediation $13(1): 6-27$.

Avery, C., J. A. Chevalier, and S. Schaefer. 1998. Why do managers undertake acquisitions? An analysis of internal and external rewards for acquisitiveness. Journal of Law, Economics and Organization 14 (1):24-43.

Baker, M., and P. A. Gompers. 2003. The determinants of board structure at the initial public offering. Journal of Law and Economics 46 (2):569-598.

BCBS. 2010. Compensation principles and standards assessment methodology. Bank for International Settlement, Basel Committee on Banking Supervision.

Bebchuk, L. A., A. Cohen, and A. Ferrel. 2009. What matters in corporate governance? The Review of Financial Studies 22 (2).

Bebchuk, L. A., and J. M. Fried. 2003. Executive compensation as an agency problem. Journal of Economic Perspectives 17:71-92.

- 2005. Pay Without Performance: Overview of the Issues. Journal of Applied Corporate Finance 17 (4):8-23.

Bebchuk, L. A., J. M. Fried, and D. I. Walker. 2002. Managerial power and rent extraction in the design of executive compensation. The University of Chicago Law Review 69 (3):751-846.

Bertrand, M., and S. Mullainathan. 2001. Are CEOs rewarded for luck? The ones without principals are. Quarterly Journal of Economics August (16:3):901-932.

Bertrand, M., and S. Mullainathan. 2003. Enjoying the quiet life? Corporate governance and managerial preferences. Journal of Political Economy 111 (5):1043-1075.

Black, L. K., and L. N. Hazelwood. 2013. The effect of TARP on bank risk-taking. Journal of Financial Stability 9:790-803.

Borokhovich, K., K. R. Brunarski, and R. Parrino. 1997. CEO contracting and antitakeover amendments. Journal of Finance 52:1495-1517.

Brickley, J. A., and C. M. James. 1987. The takeover market, corporate board composition, and ownership structure: The case of banking. Journal of Law and Economics 30:161-180.

Brown, L. D., and M. L. Caylor. 2006. Corporate governance and firm valuation. Journal of Accounting and Public Policy 25 (4):409-434.

Carpenter, J., T. Cooley, and I. Walter. 2010. Reforming compensation and corporate governance. In Regulating Wall Street: John Wiley \& Sons, Inc., 491-509.

Cary, W. L. 1974. Federalism and corporate law: reflections upon Delaware. Yale Law Journal:663-705. 
Chen, C. R., T. L. Steiner, and A. Whyte. 2006. Does stock option-based executive compensation induce risk-taking? An analysis of the banking industry. Journal of Banking \& Finance 30:915-945.

Cooper, E. W. 2009. Monitoring and governance of private banks. The Quarterly Review of Economics and Finance 49 (2):253-264.

Core, J. E., R. W. Holthausen, and D. F. Larcker. 1999. Corporate governance, chief executive officer compensation, and firm performance. Journal of Financial Economics 51 (3):371-406.

Cremers, K. J. M., and V. B. Nair. 2005. Governance mechanisms and equity prices. The Journal of Finance 60 (6):2859-2894.

Cyert, M., S.-H. Kang, and P. Kumar. 2002. Corporate governance, takeovers, and topmanagement compensation: Theory and evidence. Management Science 48 (4):453-469.

Danielson, M. G., and J. M. Karpoff. 1998. On the uses of corporate governance provisions. Journal of Corporate Finance 4 (4):347-371.

Datta, S., M. Iskandar-Datta, and K. Raman. 2001. Executive Compensation and Corporate Acquisition Decisions. The Journal of Finance 56 (6):2299-2336.

Faccio, M., J. J. McConnell, and D. Stolin. 2006. Returns to acquirers of listed and unlisted targets. Journal of Financial and Quantitative Analysis 41 (01):197220.

Fahlenbrach, R. 2009. Shareholder rights, boards, and CEO compensation. Review of Finance 13 (1):81-113.

FSB. 2009. Principles for sound compensation practices implementation standards. In Bank for International Settlement. Financial Stability Board.

Golubov, A., D. Petmezas, and N. G. Travlos. 2012. When it pays to pay your investment banker: New evidence on the role of financial advisors in M\&As. The Journal of Finance 67 (1):271-311.

Gompers, P., J. Ishii, and A. Metrick. 2003. Corporate governance and equity prices. The Quarterly Journal of Economics 118 (1):107-156.

Grinstein, Y., and P. Hribar. 2004. CEO compensation and incentives: Evidence from M\&A bonuses. Journal of Financial Economics 73:119-143.

Hagendorff, J., M. Collins, and K. Keasey. 2007. Bank Governance and Acquisition Performance. Corporate Governance: An International Review 15 (5):957-968. . 2010. Board monitoring, regulation, and performance in the banking industry: Evidence from the market for corporate control. Corporate Governance: An International Review 18 (5):381-395.

Hagendorff, J., and F. Vallascas. 2011. CEO pay incentives and risk-taking: Evidence from bank acquisitions. Journal of Corporate Finance 17:1078-1095.

Harford, J., and K. Li. 2007. Decoupling CEO wealth and firm performance: The case of acquiring CEOs. The Journal of Finance 62 (2):917-949.

Hartzell, J. C., and L. T. Starks. 2003. Institutional investors and executive compensation. The Journal of Finance 58 (6):2351-2374.

Jensen, M. 1993. The modern industrial revolution, exit, and the failure of internal control systems. The Journal of Finance XLVIII (3).

Jensen, M., and W. H. Meckling. 1976. Theory of the firm: Managerial behavior, agency costs and ownership structure. Journal of Financial Economics 3 (4):305-360.

Kirkpatric, G. 2009. The corporate governance lessons from the financial crisis. Financial Market Trends - OECD 2009/1. 
Masulis, R. W., C. Wang, and F. Xie. 2007. Corporate governance and acquirer returns. The Journal of Finance 62 (4):1851-1889.

Ozkan, N. 2012. Do CEOs gain more in foreign acquisitions than domestic acquisitions? Journal of Banking \& Finance 36 (4):1122-1138.

Renneboog, L. and Zhao, Y. (2011) Us knows us in the UK: On director networks and CEO compensation. Journal of Corporate Finance 17 (4): 1132-1157

Rosenstein, S., and J. G. Wyatt. 1990. Outside directors, board independence, and shareholder wealth. Journal of Financial Economics 26 (2):175-191.

Shleifer, A., and R. W. Vishny. 1986. Large shareholders and corporate control. The Journal of Political Economy 94 (3):461-488.

- 1997. A survey of corporate governance. The Journal of Finance 52 (2):737783.

Sierra, G., E. Talmor, and J. Wallace. 2006. An examination of multiple governance forces within bank holding companies. Journal of Financial Services Research 29 (2):105-123.

Yermack, D. 1996. Higher market valuation of companies with a small board of directors. Journal of Financial Economics 40 (2):185-211.

Yim, S. 2013. The acquisitiveness of youth: CEO age and acquisition behavior. Journal of Financial Economics 108 (1):250-273. 


\section{Table 1 \\ Descriptive statistics of M\&A deals and bidding banks}

The sample includes 214 M\&A deals in the US banking industry from 1995 to 2012. Panel A shows deal related characteristics: AMV is the acquirer's market capitalization 4 weeks before announcement, VALUE is the deal value as reported by Thomson One Banker, RELATIVESIZE is the ratio between VALUE and AMV.PAY_CASH is the proportion of the acquisition payment made in cash. TIME equals to the number of days between the announcement date and the completion date divided by 365 . CAR3 is the 3-day bidder announcement return over the $(-1,+1)$ event window, measured using the market model with parameters estimated from 200 days to 29 days before the merger announcement. CRSP value-weighted index is used as the market benchmark. GDIV is a dummy variable that equals one if the bidder and target have headquarters in different states. PUBLICTARGET is a dummy variable that equals one if the target is publically traded, and 0 otherwise. SAMECEO is a dummy variable that equals one if the CEO remains until the end of the completion year. INTERNAL (EXTERNAL) is a dummy variable that indicates whether the pre-merger CEO is replaced by an internally (externally) hired CEO after the merger. Panel B shows fixed effect variables. "Region" includes the nine US Census-Bureau designated regions. Under Industrial Classification, we classify banks according to their SIC codes. Acquiring CEO gender and education are dummy variables that equal 1 if bidding bank CEO is MALE and holds an MBA, respectively. In Panel C, we compare the financial characteristics of bidding banks before and after the acquisition. The data are obtained for the fiscal year before merger announcement and the fiscal year of merger completion. EQUITY is the book value of common equity, ASSET is the book value of total assets, $\mathrm{M} / \mathrm{B}$ is calculated as the market value of total assets, ROA is calculated using net income divided by book value of total assets, RETURN is the annual stock return for the whole fiscal year. LEVERAGE is defined as the book value of total assets divided by book value of equity. RISK is the standard deviation of daily stock returns over the whole fiscal year. *, **, and *** indicate significance at $10 \%, 5 \%$ and $1 \%$, respectively.

Panel A. Deal Characteristics

\begin{tabular}{lrrrrr}
\hline & Mean & Std. Dev. & $5 \%$ & Median & $95 \%$ \\
\hline AMV $(\$ \mathrm{~m})$ & 3,453 & 12,651 & 115 & 397 & 17,186 \\
VALUE $(\$ \mathrm{~m})$ & 1,096 & 4,648 & 24 & 97 & 5,866 \\
RELATIVESIZE & 0.307 & 0.235 & 0.109 & 0.223 & 0.796 \\
PAY_CASH & 0.227 & 0.363 & 0 & 0 & 1 \\
TIME & 0.449 & 0.153 & 0.253 & 0.433 & 0.689 \\
CAR3 & $-1.65 \%$ & $6.12 \%$ & $-9.74 \%$ & $-1.03 \%$ & $4.97 \%$ \\
GDIV & 0.341 & & & & \\
PUBLICTARGET & 0.696 & & & & \\
SAMECEO & 0.846 & & & &
\end{tabular}


Table 1 - Continued

Panel B. Fixed Effects Variables and CEO Status

\begin{tabular}{lcc}
\hline Region & Acquirer $\%$ & Target $\%$ \\
\hline Northeast: New England & 8.9 & 7.0 \\
Northeast: Mid-Atlantic & 22.9 & 21.5 \\
Midwest: East North Central & 16.4 & 15.9 \\
Midwest: West North Central & 2.8 & 1.9 \\
South: South Atlantic & 22.4 & 24.3 \\
South: East South Central & 7.0 & 7.0 \\
South: West South Central & 9.3 & 10.7 \\
West: Mountain & 0.5 & 1.4 \\
West: Pacific & 9.8 & 10.3 \\
& & \\
\hline Industrial Classification (SIC Codes) & Acquirer \% & Target \% \\
\hline National Commercial Banks (SIC 6021) & 63.1 & 61.2 \\
State Commercial Banks (SIC 6022) & 27.6 & 32.2 \\
Bank Holding Companies (SIC 6712 and 6029) & 9.3 & 6.5 \\
& & \\
\hline Acquiring CEO Gender and Education & $\%$ & \\
\hline Male & 96.7 & \\
MBA & 26.8 & \\
\hline & & \\
\hline
\end{tabular}

Panel C. Bidding Bank Financial Characteristics

C.1 Fiscal Year Prior to Merger Announcement

\begin{tabular}{lrrrrr}
\hline & Mean & Std. Dev. & $5 \%$ & Median & $95 \%$ \\
\hline EQUITY $(\$ \mathrm{~m})$ & 1,652 & 5,721 & 57 & 230 & 8,908 \\
ASSET $(\$ \mathrm{~m})$ & 20,804 & 77,959 & 593 & 2,433 & 91,644 \\
M/B & 1.087 & 0.061 & 1.004 & 1.091 & 1.177 \\
ROA & 0.011 & 0.004 & 0.006 & 0.011 & 0.016 \\
RETURN & 0.112 & 0.242 & -0.262 & 0.119 & 0.506 \\
LEVERAGE & 11.414 & 2.448 & 7.595 & 11.273 & 15.554 \\
RISK & 0.02 & 0.008 & 0.010 & 0.018 & 0.034
\end{tabular}

C.2 Fiscal Year of Merger Completion

\begin{tabular}{lrrrrr}
\hline & Mean & Std. Dev. & $5 \%$ & Median & $95 \%$ \\
\hline EQUITY $(\$ \mathrm{~m})$ & 2,592 & 9,934 & 78 & 333 & 13,529 \\
ASSET $(\$ \mathrm{~m})$ & 31,570 & 131,000 & 855 & 3,386 & 140,916 \\
MB & 1.075 & 0.065 & 0.984 & 1.068 & 1.184 \\
ROA & 0.009 & 0.004 & 0.003 & 0.01 & 0.015 \\
RETURN & 0.036 & 0.295 & -0.538 & 0.043 & 0.483 \\
LEVERAGE & 11.105 & 2.31 & 7.753 & 10.821 & 15.047 \\
RISK & 0.022 & 0.02 & 0.010 & 0.018 & 0.043
\end{tabular}


Table 1 - Continued

C.3 Change around M\&A Deals

\begin{tabular}{lllll}
\hline & Mean & t-stat & Median & Wilxon Stat \\
\hline EQUITY $(\$ \mathrm{~m})$ & $940^{* * *}$ & 2.95 & $84 * * *$ & 12.50 \\
ASSET $(\$ \mathrm{~m})$ & $10,768^{* * *}$ & 2.70 & $863^{* * *}$ & 12.50 \\
MB & $-0.012^{* * *}$ & -2.69 & $-0.012^{* * *}$ & 3.00 \\
ROA & $-0.002^{* * *}$ & -7.53 & $-0.001 * * *$ & 7.35 \\
RETURN & $-0.076^{* * *}$ & -2.99 & $-0.061 * * *$ & 2.70 \\
LEVERAGE & $-0.309^{* *}$ & -2.38 & $-0.129 * *$ & 2.20 \\
RISK & 0.002 & 1.48 & 0.001 & 1.03
\end{tabular}




\section{Table 2}

\section{CEO Compensation around Bank M\&As}

This table shows the levels and changes of CEO compensation of bidding banks in our M\&A sample. Sample period is 1995-2012. The "Pre-merger" data is collected for the fiscal year before merger announcement; and the "Post-merger" data is collected for the fiscal year after merger completion. Bonus is the cash component of the bonus payment, and long-term compensation includes the value of restricted stock, stock options, long term incentive plan, and other long-term elements. "Pay Mix" is calculated as the ratio of "long term" compensation over the sum of salary and bonus. Panels A, B, and C show CEO compensation data for the subsamples with continuing CEOs, internally promoted CEOs, and externally hired CEOs, respectively. All dollar values are measured in thousands. *, **, and *** indicate significance at $10 \%, 5 \%$ and $1 \%$, respectively.

\begin{tabular}{|c|c|c|c|c|c|c|c|c|}
\hline & \multicolumn{2}{|c|}{ Pre-merger } & \multicolumn{2}{|c|}{ Post-merger } & \multicolumn{4}{|c|}{ Change (Dollar Value) } \\
\hline & Mean & Median & Mean & Median & Mean & t-stat. & Median & Wilxon \\
\hline \multicolumn{9}{|c|}{ Panel A. Continuing CEOs ( $\$$ thousands) $-N=181$} \\
\hline Salary & 439 & 364 & 470 & 400 & $31 * * *$ & 2.96 & $30 * * *$ & 9.80 \\
\hline Bonus & 325 & 136 & 370 & 117 & 45 & 1.41 & $12 * *$ & 2.20 \\
\hline Long Term & 1,006 & 246 & 1,316 & 338 & $310 * *$ & 2.10 & $60 * * *$ & 4.85 \\
\hline Pay Mix & 0.995 & 0.490 & 1.216 & 0.623 & $0.221 *$ & 1.86 & $0.027 * * *$ & 2.94 \\
\hline \multicolumn{9}{|c|}{ Panel B. New CEO - Internally promoted (\$ thousands) $-N=26$} \\
\hline Salary & 462 & 368 & 403 & 364 & $-59 * * *$ & -2.89 & $-45 * *$ & 2.53 \\
\hline Bonus & 375 & 77 & 302 & 75 & -73 & -1.08 & -10 & 1.52 \\
\hline Long Term & 1,162 & 226 & 845 & 421 & -317 & -0.74 & 1 & 0.41 \\
\hline Pay Mix & 0.741 & 0.458 & 0.966 & 0.681 & 0.225 & 1.04 & 0.08 & 1.24 \\
\hline \multicolumn{9}{|c|}{ Panel C. New CEO - Externally hired (\$ thousands) - N=7 } \\
\hline Salary & 364 & 226 & 403 & 255 & 39 & 0.71 & 41 & 1.10 \\
\hline Bonus & 350 & 110 & 149 & 59 & -201 & -0.99 & 18 & 0 \\
\hline Long Term & 875 & 98 & 3,345 & 439 & 2,471 & 1.49 & $160 *$ & 1.77 \\
\hline Pay Mix & 0.658 & 0.395 & 3.716 & 1.723 & 3.059 & 1.51 & 0.996* & 1.77 \\
\hline
\end{tabular}


Table 3

\section{Corporate Governance Data}

This table shows descriptive statistics for corporate governance indicators (Panel A) and the distribution of our Corporate Governance Index (Panel B). STAG is a dummy variable that equals 1 if the firm has a staggered board. PP is a dummy variable that equals 1 if the firm has a poison pill in its bylaws in the year before merger announcement. BSIZE is the number of directors on the board. BINDEP is the percentage of directors who are not employees of the firm. DUALITY is a dummy variable that equals 1 if the CEO is also the Chairman of the board. NOMIN (COMPEN) is a dummy variable that equals 1 if the CEO also sits on the nomination (compensation) committee or there is no separate nomination (compensation) committee. TENURE is the number of years the CEO has been serving on the board as a director. HOLDING is the percentage of common shares held by the CEO. BLOCK is a dummy variable that equals 1 if the bidding bank has a large external blockholder who holds at least $5 \%$ of the common shares outstanding. DELA is a dummy variable that equals 1 if the bidding bank is incorporated in the state of Delaware. The Corporate Governance Index (CGI) combines all the above measures.

Panel A. Descriptive statistics for corporate governance variables

$\begin{array}{lcccccc} & \text { STAG } & \text { PP } & \text { BSIZE } & \text { BINDEP } & \text { DUALITY } & \text { NOMIN } \\ \text { Mean } & 0.724 & 0.206 & 13 & 0.878 & 0.533 & 0.402 \\ \text { Median } & 1 & 0 & 12 & 0.900 & 1 & 0 \\ & & & & & & \\ \text { Mean } & \text { COMPEN } & \text { TENURE } & \text { HOLDING } & \text { BLOCK } & \text { DELA } & \\ \text { Median } & 0.098 & 12 & 2.081 & 0.523 & 0.150 & \end{array}$

\section{Panel B. Distribution of CGI}

$\begin{array}{ccccc}\text { Value } & \text { Count } & \text { Percent } & \text { Cum.Count } & \text { Cum.Percent } \\ 2 & 1 & 0.5 & 1 & 0.5 \\ 3 & 5 & 2.3 & 6 & 2.8 \\ 4 & 26 & 12.2 & 32 & 15.0 \\ 5 & 28 & 13.1 & 60 & 28.0 \\ 6 & 57 & 26.6 & 117 & 54.7 \\ 7 & 36 & 16.8 & 153 & 71.5 \\ 8 & 35 & 16.4 & 188 & 87.9 \\ 9 & 20 & 9.4 & 208 & 97.2 \\ 10 & 6 & 2.8 & 214 & 100.0 \\ \text { Total } & 214 & 100.0 & 214 & 100.0\end{array}$




\section{Table 4 \\ Determinants of CEO compensation changes}

This table shows the determinants of changes in CEO salary, bonus and long term compensation for our 1995-2012 sample of bank mergers. Continuing CEOs only are considered. The dependent variables are the log changes in CEO salary ( $\triangle$ LNSALARY), bonus ( $\triangle$ LNBONUS) and long term compensation $(\triangle \mathrm{LNLT})$ between the fiscal year of merger completion and the fiscal year before merger announcement. $L N A M V$ is the natural $\log$ of bidder market capitalization 4 weeks before merger announcement. Relative Size is the ratio of deal value as reported by Thomson One Banker divided by the acquirer market value. $\mathrm{M} / \mathrm{B}$ is the market value of assets. ROA is the return on assets, calculated as net income divided by book value of total assets at the end of the fiscal year. RETURN is the annual stock return for the fiscal year. LEVERAGE measures financial leverage, calculated as book value of total assets divided by book value of equity. RISK is the daily stock return volatility over one fiscal year. All these financial variables are measured for the fiscal year before merger announcement and for the fiscal year of merger completion. CAR3 is the bidder's cumulative abnormal returns (CAR) measured over the 3-day announcement window $(-1,+1)$, with parameters estimated over $(-229,-29)$ days relative to merger announcement, using the market model and the value-weighted CRSP index as the benchmark. PAY_CASH is the ratio of payment made in cash. TIME measures the number of days between announcement date and completion date divided by 365 . PUBLICTARGET is a dummy variable that equals 1 if the target bank is publicly traded. GDIV is a dummy variable that equals 1 if the headquarters of the bidder and target are not in the same State. SUB_ATP, SUB_BOARD, SUB_BLOCKHOLDER, SUB_CEO_POWER, SUB_CEO_SHAREHOLDER, and SUB_DELAWARE are corporate governance sub-indices as defined in the paper. CGI is the overall corporate governance index, which is the sum of the sub-indices added together. We control for industry fixed effect, regional fixed effect, CEO fixed effect, financial crisis fixed effect and year fixed effect. We use White heteroskedasticity-consistent standard errors and covariances. $*, * *$, and $* * *$ indicate significance at $10 \%, 5 \%$ and $1 \%$, respectively.

Panel A. Changes in Compensation - CGI

\begin{tabular}{|c|c|c|c|}
\hline & DLNSALARY & $\Delta$ LNBONUS & $\Delta$ LNLT \\
\hline $\mathrm{C}$ & 0.508 & 0.757 & -1.165 \\
\hline LNAMV & $-0.027 * *$ & 0.010 & 0.053 \\
\hline RELATIVESIZE & 0.067 & -0.145 & $0.486^{*}$ \\
\hline $\mathrm{M} / \mathrm{B}_{-1}$ & -0.427 & -0.345 & 0.327 \\
\hline$\Delta \mathrm{M} / \mathrm{B}$ & $0.989 *$ & $-1.547 *$ & 1.567 \\
\hline $\mathrm{ROA}_{-1}$ & 7.020 & -13.940 & 34.354 \\
\hline$\triangle \mathrm{ROA}$ & 0.394 & 18.402 & 24.021 \\
\hline RETURN $_{-1}$ & 0.014 & 0.140 & 0.438 \\
\hline$\triangle$ RETURN & -0.061 & 0.196 & 0.131 \\
\hline LEVERAGE $_{-1}$ & 0.002 & 0.000 & 0.038 \\
\hline$\triangle \mathrm{LEVERAGE}$ & -0.016 & 0.020 & 0.002 \\
\hline RISK-1 $_{-1}$ & 0.699 & 3.599 & 11.189 \\
\hline$\Delta$ RISK & $-3.741 * * *$ & $-1.216^{*}$ & -0.182 \\
\hline CAR3 & 0.199 & -0.049 & -0.598 \\
\hline PAY_CASH & -0.023 & -0.062 & -0.099 \\
\hline TIME & -0.044 & -0.178 & 0.109 \\
\hline PUBLICTARGET & 0.017 & 0.028 & -0.111 \\
\hline GDIV & 0.047 & -0.067 & -0.029 \\
\hline CGI & -0.008 & $-0.054 * *$ & 0.016 \\
\hline Adj. R-squared & 0.211 & 0.065 & 0.006 \\
\hline No. of obs. & 162 & 162 & 162 \\
\hline Industry FE & Yes & Yes & Yes \\
\hline Regional FE & Yes & Yes & Yes \\
\hline CEO FE & Yes & Yes & Yes \\
\hline Financial Crisis FE & Yes & Yes & Yes \\
\hline Year FE & Yes & Yes & Yes \\
\hline
\end{tabular}


Table 4 - Continued

Panel B. Changes in Compensation - Sub-indices

\begin{tabular}{|c|c|c|c|}
\hline & DLNSALARY & $\Delta$ LNBONUS & $\Delta$ LNLT \\
\hline $\mathrm{C}$ & 0.406 & 1.255 & -1.864 \\
\hline LNAMV & $-0.027 * *$ & 0.015 & 0.039 \\
\hline RELATIVESIZE & 0.074 & -0.137 & 0.442 \\
\hline $\mathrm{M} / \mathrm{B}_{-1}$ & -0.422 & -0.697 & 1.056 \\
\hline$\Delta \mathrm{M} / \mathrm{B}$ & $0.993 *$ & $-1.729 * *$ & 2.067 \\
\hline $\mathrm{ROA}_{-1}$ & 8.641 & -16.145 & 34.940 \\
\hline$\triangle \mathrm{ROA}$ & 0.624 & 17.285 & 26.264 \\
\hline RETURN $_{-1}$ & -0.028 & 0.279 & 0.345 \\
\hline$\triangle$ RETURN & -0.101 & $0.270^{*}$ & 0.045 \\
\hline LEVERAGE $_{-1}$ & 0.006 & -0.002 & 0.033 \\
\hline$\triangle$ LEVERAGE & -0.016 & 0.019 & 0.001 \\
\hline RISK-1 $_{-1}$ & 0.826 & 4.881 & 9.081 \\
\hline$\Delta \mathrm{RISK}$ & $-3.569 * * *$ & -1.054 & -0.390 \\
\hline CAR3 & 0.236 & -0.211 & -0.255 \\
\hline PAY_CASH & -0.001 & -0.079 & -0.090 \\
\hline TIME & -0.084 & -0.267 & 0.292 \\
\hline PUBLICTARGET & 0.012 & 0.019 & -0.087 \\
\hline GDIV & 0.054 & -0.064 & -0.047 \\
\hline SUB_ATP & 0.004 & -0.002 & -0.097 \\
\hline SUB_BOARD & -0.038 & -0.060 & -0.022 \\
\hline SUB_BLOCK & -0.025 & -0.086 & 0.167 \\
\hline SUB_CEO_POWER & 0.027 & $-0.114 * *$ & 0.096 \\
\hline SUB_CEO_SHAREHOLDER & -0.026 & -0.051 & 0.050 \\
\hline SUB_DELAWARE & 0.064 & -0.016 & -0.109 \\
\hline Adj. R-squared & 0.218 & 0.057 & 0.001 \\
\hline No. of obs. & 162 & 162 & 162 \\
\hline Industry FE & Yes & Yes & Yes \\
\hline Regional FE & Yes & Yes & Yes \\
\hline CEO FE & Yes & Yes & Yes \\
\hline Financial Crisis FE & Yes & Yes & Yes \\
\hline Year FE & Yes & Yes & Yes \\
\hline
\end{tabular}




\section{Table 5}

\section{CGI and Bidder Returns}

This table shows the OLS regression results with bidder announcement returns over different event windows as dependent variable, and CGI as a key independent variable. We control for bidding bank characteristics and deal characteristics. Our sample includes 214 bank mergers (including deals with continuing CEOs and different CEOs). CAR1, CAR3, CAR5, CAR7, CAR11, CAR21 indicates bidder cumulative abnormal return over 1-day (day 0), 3-day $(-1,+1)$, 5-day $(-2,+2), 7$-day $(-3,+3), 11$-day $(-5,+5), 21$-day $(-10,+10)$ event windows. We scale up the dependent variable by 100 . CGI is our corporate governance index. LNAMV is the natural log of bidder market value 4 weeks before merger announcement, as reported by Thomson One Banker. LEVERAGE-1 is the financial leverage at the end of the fiscal year before merger announcement, calculated as book value of total asset divided by book value of total equity. $\mathrm{M} / \mathrm{B}_{-1}$ is the market-to-book ratio of assets at the end of the fiscal year before merger announcement. RETURN -1 is the stock return for the bidding banks over the whole fiscal year before merger announcement. RELATIVESIZE is the relative size of the deal, calculated as deal value, as reported by Thomson One Banker, divided by bidder market value. GDIV is a dummy variable that equals 1 if the bidder and target have headquarters in different States. PUBLICTARGET is a dummy variable that equals 1 if the target bank is publicly listed. CASH is the ratio of payment made in cash. In Panel B we control for industry fixed effects, regional fixed effects, CEO fixed effects, financial crisis fixed effects and year fixed effects. We use White heteroskedasticity-consistent standard errors \& covariances. $* * *$, and $* * *$ indicate significance at $10 \%, 5 \%$ and $1 \%$, respectively.

Panel A

\begin{tabular}{lcccccc|}
\hline & (i) & (ii) & (iii) & (iv) & (v) & (vi) \\
& CAR1 & CAR3 & CAR5 & CAR7 & CAR11 & CAR21 \\
\hline C & $-5.020^{* * *}$ & $-7.227 * * *$ & $-7.224 * * *$ & $-8.814 * * *$ & $-8.942 * * *$ & $-9.554 * * *$ \\
\hline CGI & $0.555^{* * *}$ & $0.866^{* * *}$ & $0.846^{* * *}$ & $1.086^{* * *}$ & $1.077 * * *$ & $1.070^{* * *}$ \\
\hline & & & & & & \\
Adj. R-squared & 0.057 & 0.053 & 0.048 & 0.068 & 0.052 & 0.033 \\
No. of obs. & 207 & 207 & 207 & 207 & 207 & 207 \\
\hline
\end{tabular}

Panel B

\begin{tabular}{|c|c|c|c|c|c|c|}
\hline & $\begin{array}{c}\text { (i) } \\
\text { CAR1 }\end{array}$ & $\begin{array}{c}\text { (ii) } \\
\text { CAR3 }\end{array}$ & $\begin{array}{c}\text { (iii) } \\
\text { CAR5 }\end{array}$ & $\begin{array}{c}\text { (iv) } \\
\text { CAR7 }\end{array}$ & $\begin{array}{c}\text { (v) } \\
\text { CAR11 }\end{array}$ & $\begin{array}{c}\text { (vi) } \\
\text { CAR21 }\end{array}$ \\
\hline $\mathrm{C}$ & 6.761 & 4.275 & -0.685 & -14.923 & -28.166 & -25.903 \\
\hline CGI & 0.253 & $0.621 * *$ & $0.582 * *$ & $0.745 * *$ & $0.873 * *$ & 0.813 \\
\hline LNAMV & -0.259 & 0.079 & -0.128 & 0.027 & 0.160 & 0.020 \\
\hline LEVERAGE $_{-1}$ & -0.125 & -0.198 & -0.145 & 0.099 & 0.037 & 0.188 \\
\hline $\mathrm{M} / \mathrm{B}_{-1}$ & -2.949 & -5.750 & -3.950 & 6.032 & 12.167 & 8.870 \\
\hline RETURN $_{-1}$ & -1.004 & -3.897 & -3.823 & -1.095 & 0.800 & -0.930 \\
\hline RELATIVESIZE & -2.162 & -1.194 & -1.890 & -0.938 & -0.779 & 1.469 \\
\hline GDIV & -0.952 & -1.407 & -1.721 & -0.962 & -0.924 & 1.663 \\
\hline PUBLICTARGET & -1.168 & -0.293 & 0.091 & -1.522 & -1.043 & -2.285 \\
\hline PAY_CASH & 0.002 & 0.023 & 0.016 & 0.009 & 0.005 & 0.000 \\
\hline Adj. R-squared & 0.240 & 0.136 & 0.088 & 0.118 & 0.100 & 0.043 \\
\hline No. of obs. & 195 & 195 & 195 & 195 & 195 & 195 \\
\hline Industry FE & Yes & Yes & Yes & Yes & Yes & Yes \\
\hline Regional FE & Yes & Yes & Yes & Yes & Yes & Yes \\
\hline CEO FE & Yes & Yes & Yes & Yes & Yes & Yes \\
\hline Financial Crisis FE & Yes & Yes & Yes & Yes & Yes & Yes \\
\hline Year FE & Yes & Yes & Yes & Yes & Yes & Yes \\
\hline
\end{tabular}




\section{Table 6 \\ Robustness Tests}

This table shows the determinants of CEO compensation when considering the effect of government support during the subprime crisis. TARP RECIPIENT is a dummy variable that equals to 1 if the bidding bank was a recipient of government TARP funding and the TARP assistance overlaps the period between the announcement and completion of the merger. $\triangle L N S A L A R Y$ is the natural log of salary for the fiscal year of merger completion minus the natural $\log$ of salary for the fiscal year before merger announcement. $\triangle L N B O N U S$ is the natural log of the sum of bonus post-merger and salary pre-merger minus the natural $\log$ of the sum of bonus pre-merger and salary pre-merger. $\triangle L N L T$ is the natural $\log$ of the sum of long term compensation post-merger and salary pre-merger minus the natural log of the sum of long term compensation pre-merger and salary pre-merger. $L N A M V$ is the natural log of bidder market capitalization 4 weeks before merger announcement. Relative Size is the ratio of deal value as reported by Thomson One Banker divided by the acquirer market value. All the following financial variables are measured for the fiscal year before merger announcement and for the fiscal year of merger completion. $\mathrm{M} / \mathrm{B}$ is the market value of assets. ROA is return on assets, calculated as net income divided by book value of total assets at the end of the fiscal year. RETURN is the annual stock return for the fiscal year. LEVERAGE measures financial leverage, calculated as book value of total assets divided by book value of equity. RISK is the daily stock return volatility over one fiscal year. CAR3 is the bidder's cumulative abnormal returns (CAR) measured over the 3-day announcement window $(-1,+1)$, using the market model and the value-weighted CRSP index as the benchmark. PAY_CASH is the ratio of payment made in cash. TIME measures the number of days between announcement date and completion date divided by 365 . PUBLICTARGET is a dummy variable that equals 1 if the target bank is publicly traded. GDIV is a dummy variable that equals 1 if the headquarters of the bidder and target are not in the same State. CGI is our corporate governance index. We control for industry fixed effects, regional fixed effects, CEO fixed effects, financial crisis fixed effects and year fixed effects. We use White heteroskedasticityconsistent standard errors \& covariance. *, **, and $* * *$ indicate significance at $10 \%, 5 \%$ and $1 \%$, respectively.

\begin{tabular}{|c|c|c|c|}
\hline & DLNSALARY & $\triangle \mathrm{LNBONUS}$ & $\Delta$ LNLT \\
\hline $\mathrm{C}$ & 0.314 & 0.717 & -1.004 \\
\hline LNAMV & -0.014 & 0.017 & 0.053 \\
\hline RELATIVESIZE & 0.086 & -0.143 & 0.466 \\
\hline $\mathrm{M} / \mathrm{B}-1$ & -0.381 & -0.322 & 0.318 \\
\hline$\Delta \mathrm{M} / \mathrm{B}$ & 0.791 & $-1.750 * *$ & 1.390 \\
\hline ROA-1 & 2.710 & -17.951 & 31.383 \\
\hline$\triangle \mathrm{ROA}$ & 0.094 & 18.473 & 24.548 \\
\hline RETURN-1 & 0.028 & 0.153 & 0.445 \\
\hline$\triangle$ RETURN & -0.085 & 0.214 & 0.197 \\
\hline LEVERAGE-1 & 0.005 & 0.001 & 0.037 \\
\hline$\triangle$ LEVERAGE & -0.003 & 0.026 & -0.001 \\
\hline RISK-1 & 2.606 & 5.082 & 11.893 \\
\hline$\Delta$ RISK & $-3.398 * * *$ & $-1.183^{*}$ & -0.546 \\
\hline CAR3 & 0.574 & 0.140 & -0.675 \\
\hline PAY_CASH & -0.043 & -0.064 & -0.077 \\
\hline TIME & -0.082 & -0.193 & 0.124 \\
\hline PUBLICTARGET & 0.026 & 0.024 & -0.132 \\
\hline GDIV & 0.041 & -0.073 & -0.035 \\
\hline CGI & -0.007 & $-0.055^{* *}$ & 0.012 \\
\hline TARP_RECIPIENT & $-0.415 * *$ & $-0.307 *$ & -0.120 \\
\hline TARP RECIPIENT* ${ }^{*} \Delta$ RISK & $-10.988 * *$ & 1.056 & 16.032 \\
\hline Adjusted R-squared & 0.268 & 0.065 & -0.006 \\
\hline No. of Observations & 162 & 162 & 162 \\
\hline Year dummies & Included & Included & Included \\
\hline Industry FE & Yes & Yes & Yes \\
\hline Regional FE & Yes & Yes & Yes \\
\hline CEO FE & Yes & Yes & Yes \\
\hline Financial Crisis FE & Yes & Yes & Yes \\
\hline Year FE & Yes & Yes & Yes \\
\hline
\end{tabular}




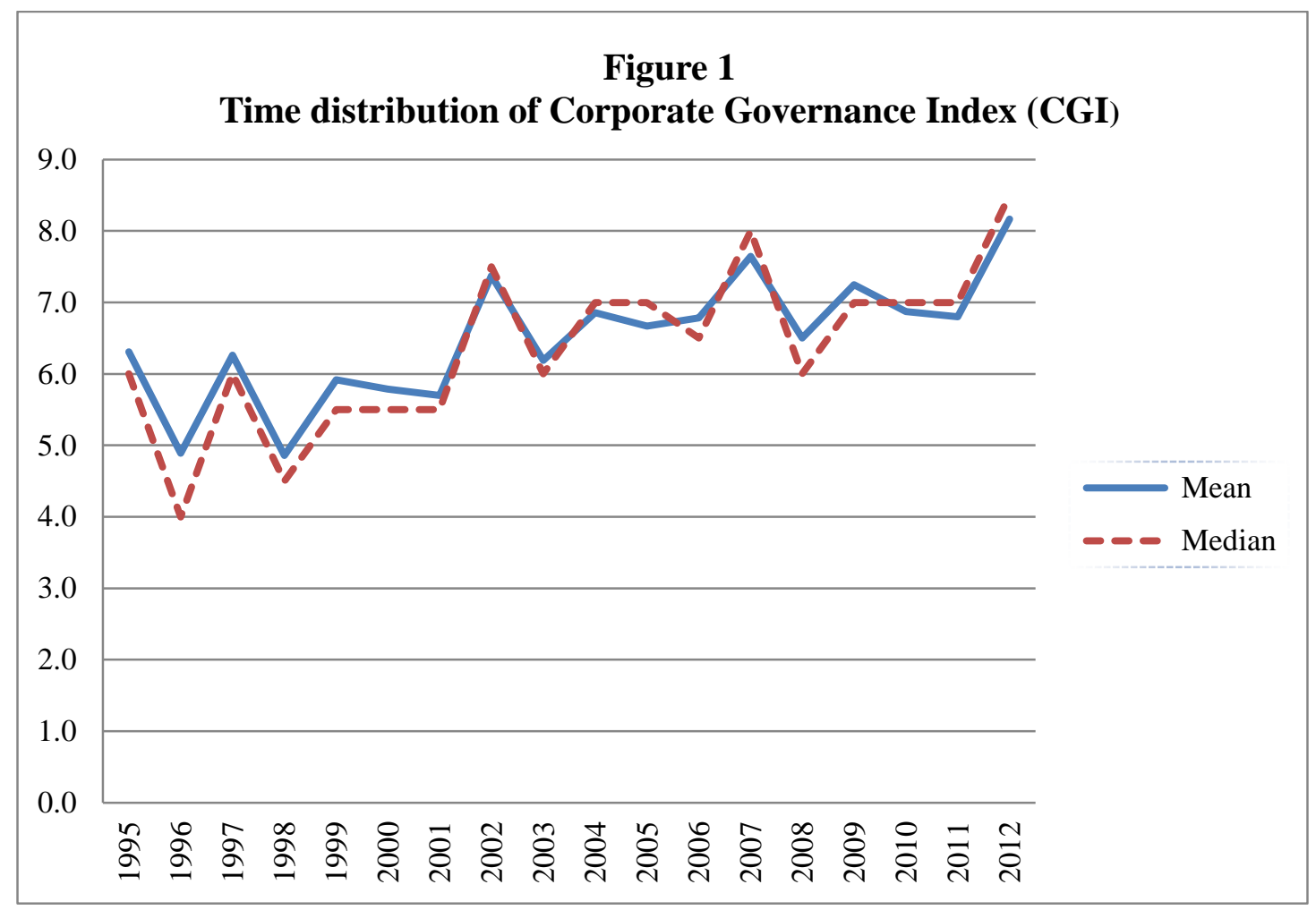

